\title{
SISTEM INFORMASI BERBASIS WEB UNTUK MENGETAHUI BENCANA PADA BADAN PENANGGULANGAN BENCANA DAERAH KABUPATEN KUDUS
}

\author{
Esti Wijayanti \\ Progam Studi Teknik Informatika, Fakultas Teknik, Universitas Muria Kudus \\ Email: esti.wijayanti@umk.ac.id
}

(Naskah masuk: 5 November 2020, diterima untuk diterbitkan: 25 Juni 2021)

\begin{abstract}
Abstrak
Bencana yang selama ini tidak dapat kita ketahui kapan bencana tersebut terjadi pada perancangan sistem ini bertujuan untuk memberikan kemudahan masyarakat dalam mengetahui informasi terkait kebencanaan, informasi geografis tentang bencana, dan nomor penting apabila dalam keadaan darurat, selain melalui media social yang ada, juga bisa melalui sistem informasi tersebut. pada pengembangan perangkat lunak yang akan dibangunadalah bebasis website berbasis php dan mysql, dengan menggunakan metode waterfall pada tahapan analisis, merancang, implementasi, pengujian, dan perawatan. Aplikasi telah berhasil dikembangkan perangkat lunak aplikasi berbasis web untuk mengetahui bencana di kudus pada badan penanggulangan bencana daerah kabupaten kudus. Kesimpulan dari keseluruhan proses adalah membantu dan mempermudah warga untuk mengetahui bencana yang ada di kudus.
\end{abstract}

Kata kunci: sistem, mitigasi, kebencanaan

\section{WEB-BASED INFORMATION SYSTEM FOR FIND KNOW DISASTROUSIN ON REGIONAL DISASTER MANAGEMENT AGENCY KUDUS REGENCY}

\begin{abstract}
Disasters that we can not know when the disaster occurred in the design of this system aims to make it easier for the public to know information related to disasters, geographical information about disasters, and important numbers if in an emergency, in addition to through existing social media, can also go through the information system. on the development of software to be built is a freeis website based on php and mysql, using waterfall methods at the stage of analysis, designing, implementation, testing, and maintenance. The application has been successfully developed web-based application software to find out the disaster in kudus on the disaster management agency of the sacred district area. The conclusion of the whole process is to help and make it easier for citizens to know the disaster that exists in kudus.
\end{abstract}

Keywords: systems, mitigation, disasters

\section{PENDAHULUAN}

Pemanfaatan dan pengembangan sistem informasi yang diterapkan teknologi internet pada instansi pemerintahan semakin banyak dilakukan untuk membantu dalam mempermudah kerja para staff dan keefektifan waktu dan biaya. Kantor Badan Penanggulangan Bencana Daerah Kabupaten Kudus memang sudah melakukan pemanfaatan teknologi di berbagai sektor. Namun untuk sistem informasi, mereka mengandalkan media sosial yang sudah ada untuk memberikan informasi terkini kepada masyarakat. Belum hadirnya sistem informasi berupa website. Sehingga masyarakat dapat mengetahui informasi terkait kebencanaan, informasi infografis bencana, dan nomor penting apabila dalam keadaan darurat selain melalui media social yang ada, juga bisa melalui sistem informasi tersebut.

Secara geografis Kantor Badan Penanggulangan Bencana Daerah Kabupaten Kudus berlokasi di alamat Gg. 3 Kav., Mlati Norowito, Kec. Kota Kudus, Kabupaten Kudus, Jawa Tengah 59319, Indonesia dengan nomor telpon (0291) 425002.

Data yang digunakan penelitian ini adalah dari data Kantor Badan Penanggulangan Bencana Daerah Kabupaten Kudus (BPBD, 2019).

\section{METODE}

Metode yang dikembangkan untuk pembuatan system website ini yaitu website berbasis php dan mysql, dengan menggunakan metode waterfall 
seperti yang ditunjukkan pada gambar dibawah ini yang diimplementasikan pada websitenya dengan tujuan menghasilkan website yang dapat meningkatkan pelayanan dapat dilihat pada gambar 1.

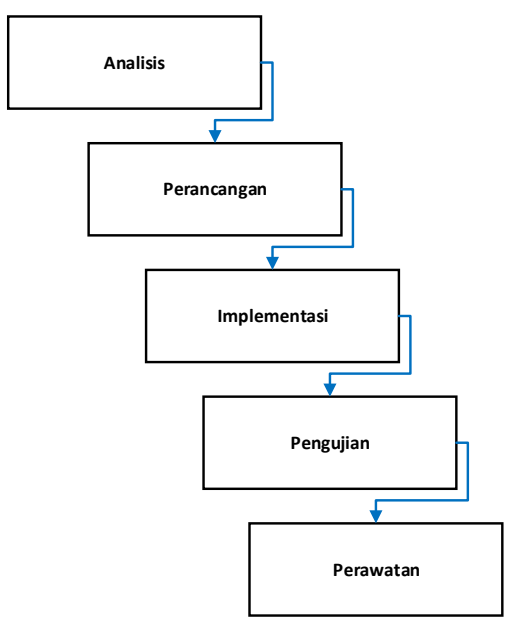

Gambar 1. Tahap Metode Waterfall

Beberapa tahapan model waterfall dalam pengembangan sistem yang akan dibangun meliputi:

a. Analisis

Tahap ini melakukan analisa terhadap objek penelitian. Dengan tujuan menganalisa kebutuhan data dan informasi, serta kebutuhan sistem.

b. Perancangan

Tahap ini merupakan inti dari rancang bangun sebuah proses. Hal ini dilakukan guna menyusun website baik.

c. Implementasi

Tahap ini merupakan penyelesaian desain sistem yang sudah dirancang. Dengan tujuan desain system sudah selesai dirancang.

d. Pengujian

Tahapan ini merupakan website terselesaikan, serta sudah teruji ke beberapa sample user dengan tujuan website berjalan dengan baik.

e. Perawatan

Tahapan ini merupakan proses perawatan setelah website berjalan. Dengan tujuan website selalu uptodate dengan bertambahnya data.

\section{HASIL DAN PEMBAHASAN}

\subsection{Flowchart}

Flowchart merupakan urutan langkah kerja suatu proses yang digambarkan dengan menggunakan simbol-simbol yang disusun secara sistematis. Untuk itu maka dibuatlah alur programnya atau lebih sering disebut flowchart supaya lebih mudah dalam pembuatannya. Seperti ditunjukkan pada gambar 2 .

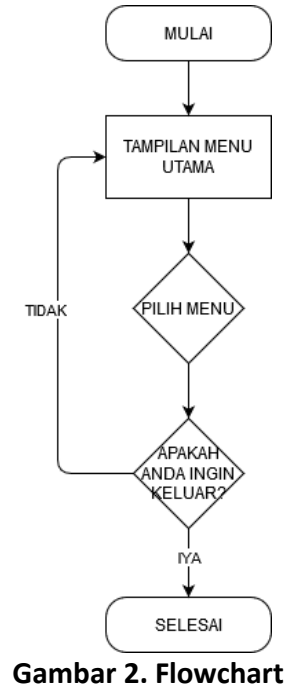

3.2 DFD

Data Flow Diagram (DFD) adalah alat pembuatan model yang memungkinkan profesional sistem untuk menggambarkan sistem sebagai suatu jaringan proses fungsional yang dihubungkan satu sama lain dengan alur data, baik secara manual maupun komputerisasi.

Untuk itu maka dibuatlah DFD seperti ditunjukkan pada gambar 3 .

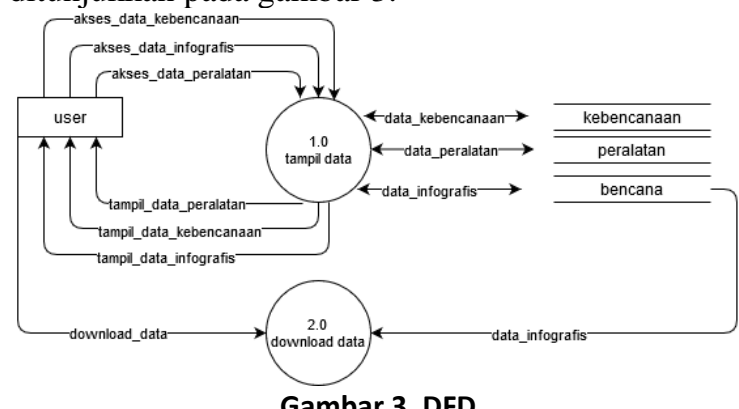

\subsection{ERD}

Entity Relationship Diagram (ERD), yaitu sebuah model untuk menyusun database agar dapat menggambarkan data yang mempunyai relasi dengan database yang akan didesain. Pada sistem informasi ini memiliki hubungan kardinalitas one to many, seperti yang ditunjukkan pada gambar 4 . 


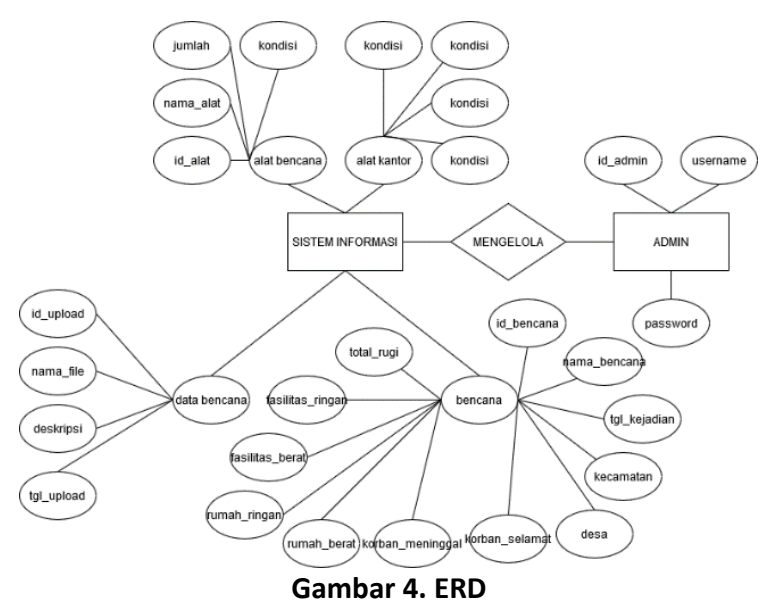

\subsection{Halaman Utama}

Pada halaman ini berisi informasi relawan dari Badan Penanggulangan Bencana Daerah Kabupaten Kudus. Jadi masyarakat dapat menghubungi relawan untuk bertanya terkait informasi kebencanaan, seperti yang ditunjukan pada gambar 5 .

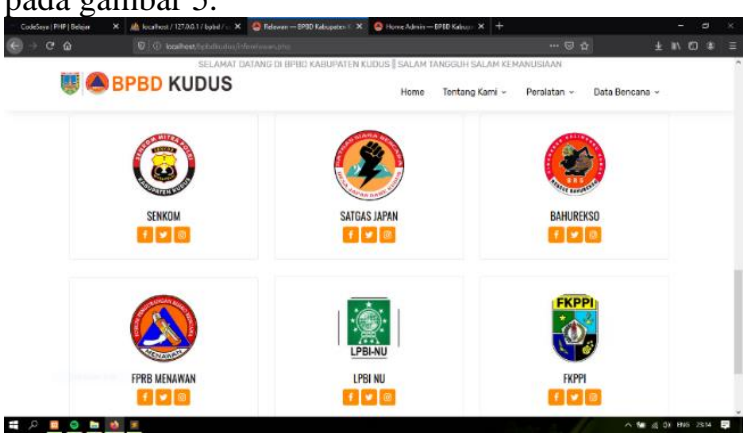

Gambar 5. Tampilan Halaman Relawan

\subsection{Halaman Informasi Geografis}

Pada halaman ini berisi informasi infografis bencana dari Badan Penanggulangan Bencana Daerah Kabupaten Kudus, seperti yang ditunjukan pada gambar 6 berikut

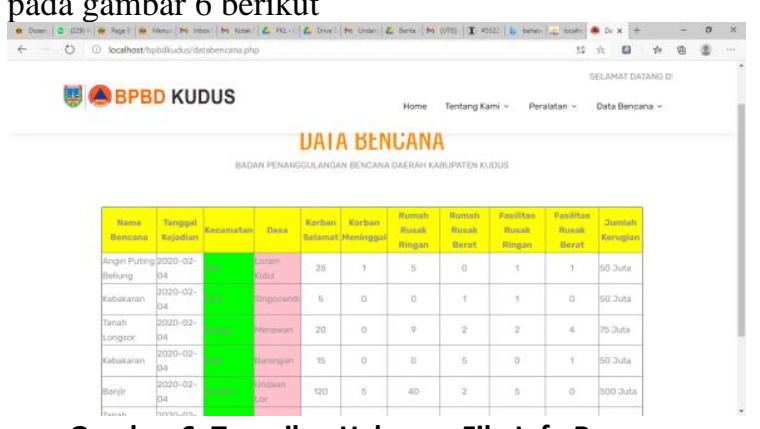

Gambar 6. Tampilan Halaman File Info Bencana

\subsection{Halaman Informasi Penting}

Pada halaman ini berisi Info atau nomor penting dari Badan Penanggulangan Bencana Daerah Kabupaten Kudus, seperti yang ditunjukan pada gambar 7 berikut

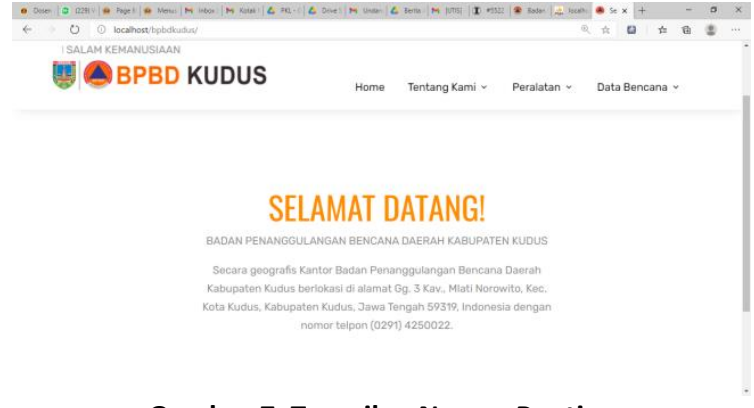

Gambar 7. Tampilan Nomor Penting

\section{SIMPULAN DAN SARAN \\ 4.1 Simpulan}

Dari uji coba perancangan sistem pendataan santunan kematian di Badan Penanggulangan Bencana Daerah Kabupaten Kudus, dapat diambil beberapa kesimpulan, diantaranya:

1. Mempermudah masyarakat untuk dapat mengetahui informasi terkait kebencanaan melalui relawan maupun pihak bpbd secara langsung, informasi infografis bencana selain dari media social bpbd.

2. Masyarakat juga bisa mengetahui nomor penting apabila dalam keadaan darurat selain melalui media social yang ada, juga bisa melalui sistem informasi tersebut.

\subsection{Saran}

Dalam pembuatan Aplikasi dikembangkan berbasis android dan realtime

\section{DAFTAR PUSTAKA}

Al-Bahra Bin Ladjamudin. 2005. "AnalisisdanDesain Sistem Informasi". Graha Ilmu. Yogyakarta.

Darvis, G. dkk. 1999. "Analisa dan Perancangan Manajemen Sistem "JAKARTA PT. GRAMEDIA.

Fiati.,R., Wijayanti.,E.,2017. Ipteks bagi Masyarakat Kerajinan Miniatur di Desa Bacin Kab.Kudus, Laporan pengabdian Masyarakat, Universitas Muria Kudus

Herliana, Astri, dkk. 2016. " Sistem Informasi Monitoring Pengembangan Software Pada Tahap Development Berbasis Web”. Bina Sarana Informatika. Bandung.

Jogiyanto, H. M. 2005. "Analisis dan Desain Sistem Informasi Edisi Ketiga”. Yogyakarta: C.V Andi Offset.

Mudjahidin, \& Putra, N. P. 2010. "Rancang Bangun Sistem Informasi Monitoring Perkembangan Proyek Berbasis Web Studi Kasus Di Dinas Bina Marga dan Pemantusan. Jurnal Teknik Industri" Vol.11 No.1, 75-83. 
54 Indonesian Journal of Technology, Informatic and Science (IJTIS), Vol. 2, No. 2, Juni 2021, hlm. 51-54

Pressman, RogerS. 2001. "Software Engineering: A Practioner's Approach”, Fifth Edition, MacGraw-Hill International Editions.

Sanjani, L. A., Hartati, S. J., \& Sudarmaningtya, P. 2014. "Rancang Bangun Sistem Informasi Penggajian Pegawai dan Remunerasi Jasa Medis Pada Rumah Sakit Bedah Surabaya". Jurnal Sistem Informasi Vol.3 No.1, 87-93.

Saputro H., Wijayanti, E., 2020. Rekayasa Perangkat Lunak Sebagai Syarat-Syarat Izin Mendirikan Bangunan Dinas Penanaman Modal Dan Pelayanan Terpadu Satu Pintu ( DPMPTSP ) Kudus Dengan Metode V, Vol 1, No 2.

Sutabri, T. 2012. "Konsep Sistem Informasi". Yogyakarta : C.V. Andi Offset. 